\title{
Assessment of Microleakage of a Composite Resin Restoration in Primary Teeth Following Class III Cavity Preparation Using Er, Cr: YSGG laser: An In Vitro Study
}

\author{
Priya Subramaniam*, Annu Pandey \\ Department of Pedodontics and Preventive Dentistry, The Oxford Dental College and Hospital, Hosur Road, Bomanahalli, \\ Bangalore 560068, India
}

\author{
*Correspondence to \\ Priya Subramaniam, MDS. \\ Department of Pedodontics and \\ Preventive Dentistry, The Oxford \\ Dental College and Hospital, Hosur \\ Road, Bomanahalli, Bangalore \\ 560068, India \\ Tel: +91-8030219733; + 98- \\ 44225624; \\ Fax: +91-8025734656 \\ Email: drpriyapedo@yahoo.com
}

Published online 18 July 2016

\begin{abstract}
Introduction: Marginal seal integrity is important for a successful adhesive dental restoration. Alterations caused by laser irradiation in the enamel and dentin surface can affect the marginal integrity of adhesive restorations. The aim of this study was to evaluate the microleakage of a composite resin restoration in primary teeth following laser irradiation of enamel and dentin.

Methods: Forty freshly extracted sound human primary maxillary and mandibular anterior teeth were used in this study. The teeth were randomly divided into two groups (I and II), with 20 teeth in each. In group I, proximal cavities (Class III) were prepared using an airotor hand -piece and diamond bur. The cavities were etched for 15 seconds with 35\% phosphoric acid gel, rinsed with water for 15 seconds, air dried and a bonding agent was applied onto the cavity surfaces and light cured for 20 seconds. The cavities were restored with composite resin and light cured for 40 seconds. In group II, proximal (Class III) cavities were prepared using Erbium, Chromium: Yttrium Scandium Gallium Garnet (Er,Cr:YSGG) (Er,Cr:YSGG) (Biolaseiplus, wave length $2.78 \mu \mathrm{m}$ ). The cavity was then rinsed, air dried and without etching, a bonding agent was applied and light cured for 20 seconds. The cavities were restored in the same manner as that of group I. The treated teeth were mounted on acrylic resin blocks and were subjected to a thermocycling regimen. Following, the teeth were immersed in $2 \%$ methylene blue for 24 hours. The teeth were sectioned longitudinally in a bucco-lingual direction using a diamond disc at slow speed. The sections of all the groups were examined under a stereomicroscope for micro-leakage.

Results: The mean scores for microleakage in group I was $1.95 \pm 1.31$ and in group II it was $1.4 \pm 1.27$. There was no significant difference between the two groups $(P=0.882)$. Conclusion: No significant difference in microleakage was noticed between the composite resin bonded to lased enamel and dentin and the teeth preparedwith conventional method. Keywords: microleakage; laser; cavity preparation; dental; primary teeth.
\end{abstract}

\section{Introduction}

Modern operative pediatric dentistry has moved to a minimally invasive approach, in which dental caries is managed as an infectious disease and the focus is on maximum conservation of tooth structures. The advent of lasers has offered new possibilities in the management of children in pediatric dentistry where caries removal and cavity preparation are performed with minimal tissue removal. Laser applications on hard tissues include caries prevention and detection, cavity preparation and for sealing of pits and fissures. The American Academy of Pediatric Dentistry (AAPD) in its policy has stated that lasers can be an alternative method for treating both hard and soft tissues in children. ${ }^{1}$ Dental lasers offer many ad- vantages when treating children. Unlike the traditional dental drill, lasers work on hard tissue without coming in contact with the tooth. It does not generate vibrations and noise and it is less painful, especially for patients who have dental anxiety. ${ }^{2}$

Erbium lasers such as Erbium:Yttrium Aluminum Garnet (Er:YAG) and Erbium, Chromium: Yttrium Scandium Gallium Garnet (Er,Cr:YSGG) have been used in restorative treatment of dental hard tissues and are highly absorbed in water. ${ }^{2}$ Er,Cr:YSGG lasers can irradiate dentin of primary teeth, with minimal thermal effects on surrounding tissues. ${ }^{3}$

Marginal seal integrity is important for a successful adhesive dental restoration. The marginal integrity of adhesive

Please cite this article as follows: Subramaniam P, Pandey A. Assessment of microleakage of a composite resin restoration in primary teeth following class III cavity preparation using Er, Cr: YSGG laser: an in vitro study. J Lasers Med Sci. 2016;7(3):172-176. doi:10.15171/ jlms.2016.30. 
restorations may get affected due to surface alterations caused by laser irradiation. ${ }^{4}$

Certain studies have found improved adhesion and less microleakage with laser irradiation. ${ }^{5,6}$ Lower microleakage has been observed in tooth surfaces irradiated by lasers. ${ }^{7-9}$ Studies investigating microleakage of composite restorations following the application of lasers have primarily focused on permanent teeth and also on the type of adhesive systems employed. ${ }^{1,710,11}$ Primary dentin has been assumed to be different from permanent dentin due to the variable amounts of mineral components, as well as different morphology and structure. ${ }^{12}$ Hence, the objective of this study was to evaluate the microleakage of a composite resin restoration in primary teeth following laser irradiation of enamel and dentin.

\section{Methods}

Forty freshly extracted intact human primary upper and lower anterior teeth were used in this study. These teeth were extracted as they were over retained or were causing excessive discomfort to the child due to preshedding mobility. Teeth that were free of cracks, restorations, caries and other imperfections/anomalies were included in the study. The selected teeth were stored in $0.1 \%$ thymol solution until the experiment was carried out.

The surfaces of teeth were debrided using hand scalers and cleaned with pumice slurry. They were then mounted on acrylic resin blocks such that only their crowns were exposed. The teeth were randomly divided into two groups (I and II), with 20 teeth in each one. In group I, proximal cavities were prepared using an airotor handpiece (NSK, Japan) and diamond bur (No 4, No 169L, No 330FG). The cavity dimensions were as follows: 0.5 to $1 \mathrm{~mm}$ deep, $2 \mathrm{~mm}$ each in height and width. Following cavity preparation, the teeth were washed with water and the cavities were air-dried with oil-free compressed air. The cavities were etched for 15 seconds with 35\% phosphoric acid gel (Scotchbond ${ }^{\mathrm{TM}}$ Multi-Purpose Etchant, $3 \mathrm{M}$ ESPE), rinsed with water for 15 seconds and air dried. A bonding agent (Adper ${ }^{\mathrm{TM}}$ Single Bond 2 Adhesive, 3M ESPE) was applied on the cavity surfaces, air dried and light cured for 20 seconds. The cavities were restored with composite resin (Filtek ${ }^{\mathrm{TM}} 350 \mathrm{XT}, 3 \mathrm{M}$ ESPE) and light cured for 40 seconds.

In group II, Er, Cr:YSGG laser (Biolaseiplus Technology, Inc, USA) (Wave length: $2.78 \mu \mathrm{m}$, Maximum output power:10 W, Maximum pulse energy: $600 \mathrm{Mj}$, Pulse repetition rate- 5: $100 \mathrm{~Hz}$, Pulse duration; 600-700 $\mu \mathrm{m}$, Spot size: $0.442 \mathrm{x} \mathrm{mm}^{2}$ ) was used to prepare proximal cavities. Laser irradiation was done by using a turbo handpiece, which was placed $8-10 \mathrm{~mm}$ away from the teeth. Laser irradiation $(4 \mathrm{~W}, 15 \mathrm{~Hz})$ at $60 \%$ air-water level was used to remove enamel. On reaching the dentino-enamel junction, the laser energy was reduced to $3 \mathrm{~W}$ at $60 \%$ air level and $30 \%$ water level, and cavity preparation was carefully completed. The cavity was then rinsed, air dried and was not etched. Application of bonding agent and restoration of the cavities was carried out in a manner similar to that of group I.

All teeth samples were transferred in a sealed container containing distilled water to laboratory and stored at $37^{\circ} \mathrm{C}$ for 24 hours. The teeth were subjected to 500 thermocycles, at temperature between $5{ }^{\circ} \mathrm{C}$ and $55^{\circ} \mathrm{C}$, using a water bath. ${ }^{7}$ The entire tooth was covered with nail varnish, except for a small area of $4 \mathrm{~mm}$ around the margins of the prepared cavity. The teeth were immersed in $2 \%$ methylene blue for 24 hours, rinsed in tap water and the superficial dye was gently removed using pumice slurry and a rubber cup. A diamond disc at slow speed was used to section the teeth longitudinally in a bucco-lingual direction at the centre of the cavity in order to obtain two halves. The sections of all the groups were examined under a stereomicroscope (Lawrence and Mayo, USA) at 32 $\mathrm{X}$ magnification for micro-leakage. Microleakages were scored according to the criteria given by Ovrebo and Raadal as: ${ }^{13}$

$0=$ Absence of dye penetration (Figure 1A)

$1=$ Penetration of dye through margin of cavity up to enamel (Figure 1B)

$2=$ Penetration of dye through margin of cavity up to dentin (Figure 1C)

$3=$ Penetration of dye through cavity margin and involving floor of cavity (Figure 1D)

Data obtained was subjected to statistical analysis using unpaired independent $t$ test and SPSS 19. The $P$ value $\leq$ 0.05 was considered as significant and $P<0.001$ was taken as highly significant.

\section{Results}

The mean scores for microleakage were $1.95 \pm 1.31$ in group I and $1.4 \pm 1.27$ in group II. No significant difference was seen between the two groups $(P=0.882$; Table 1). No microleakage (score 0; Figure 1A) was detected in $5(25 \%)$ conventional cavities (group I) and in 7 (35\%) laser etched cavities (group II). In Table 2, 11 (55\%) con-
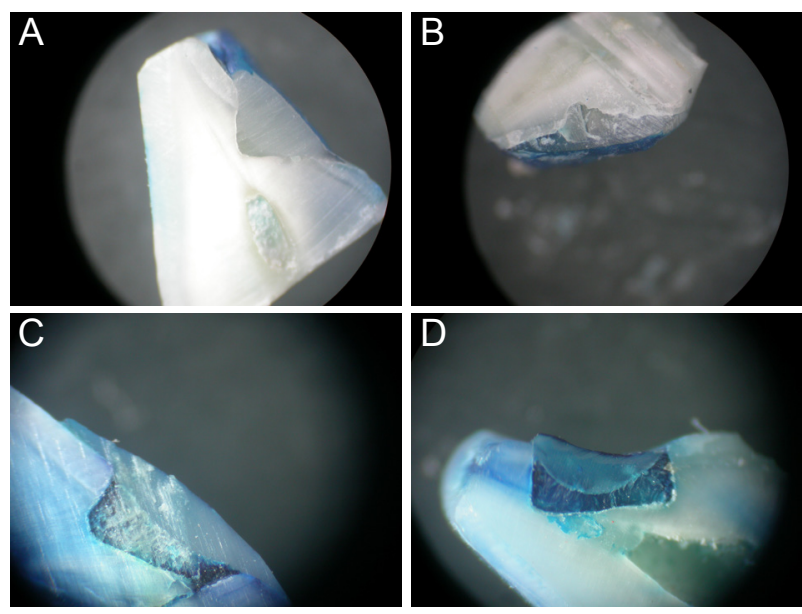

Figure 1. (A) Absence of dye penetration; (B) Penetration of dye through margin of cavity up to enamel; (C) Penetration of dye through margin of cavity up to dentin; (D) Penetration of dye through cavity margin and involving floor of cavity. 
Table 1. Comparison of Mean Scores for Microleakage Between the Groups

\begin{tabular}{lccc}
\hline Groups & $\mathbf{n}$ & Mean \pm SD & $\boldsymbol{P}$ Value \\
\hline Group I $^{\mathrm{a}}$ & 20 & $1.95 \pm 1.32$ & 0.882 \\
Group II $^{\mathrm{b}}$ & 20 & $1.4 \pm 1.27$ & \\
\hline
\end{tabular}

${ }^{a}$ Conventional technique; ${ }^{b}$ Laser technique.

Table 2. Distribution of Teeth According to Microleakage Scores

\begin{tabular}{lcc}
\hline Scores Obtained & $\begin{array}{c}\text { Group I } \\
\mathbf{n}(\%)\end{array}$ & $\begin{array}{c}\text { Group II } \\
\mathbf{n}(\%)\end{array}$ \\
\hline $\begin{array}{l}0=\text { No dye penetration } \\
\text { 1=Dye penetration reaching enamel }\end{array}$ & $5(25 \%)$ & $7(35 \%)$ \\
$\begin{array}{l}\text { tissue } \\
2=\text { Dye penetration reaching dentin } \\
\text { tissue }\end{array}$ & $2(10 \%)$ & $4(20 \%)$ \\
$\begin{array}{l}3=\text { Dye penetration reaching the cavity } \\
\text { floor }\end{array}$ & $11(55 \%)$ & $6(30 \%)$ \\
\hline
\end{tabular}

ventional cavities (group I) and 6 (30\%) laser etched cavities (group II) showed complete microleakage (score 3; Figure 1D).

\section{Discussion}

Restoration of interproximal caries in primary anterior teeth can be quite challenging due to their small crown size, lesser enamel thickness and relatively larger pulp chambers. Conservative cavities are indicated in primary teeth with consideration to the depth of cavity preparation and restorative material placed. Control of moisture, bleeding at the gingival margins and retention of the rubber dam could be difficult to achieve in order to obtain a successful result. In many instances, the retention of very small restorations is compromised due to inadequate preparation of the tooth. ${ }^{14}$

Irradiation with Er,Cr:YSGG laser is advantageous to remove carious enamel and dentin or to prepare cavities in pediatric dentistry because it does not damage the surrounding tissues. ${ }^{1}$ During cavity preparation, thermal damage to the underlying pulp can be prevented by using an adequate water spray and with a careful irradiation technique. ${ }^{15} \mathrm{~A}$ few studies have been conducted on the use of Er,Cr:YSGG lasers in primary teeth..$^{3,16,17}$ Most of them have reported ultra-structural morphological changes following cavity preparation, as observed under a scanning electron microscope. ${ }^{3,16}$ Since surface texture of both enamel and dentine are altered following laser irradiation, it is necessary to assess the effect of Er,Cr:YSGG laser on microleakage.

Laser energy with 60\% air and 30\% water level was used for cavity preparation. In spite of most radiation being absorbed by water, a certain amount of heat transmission cannot be avoided. Therefore, cooling with a water spray was done to prevent damage to surrounding tissues and pulp. ${ }^{17,18}$ Hence, at the start of cavity preparation, laser irradiation was performed in a non-contact mode with maximum energy density of $5 \mathrm{~W}$. The dentin thickness overlying the pulp of primary teeth is relatively thin, and has wider dentinal tubules. ${ }^{19}$ Therefore, on reaching the dentino-enamel junction, and while preparing the floor of the cavity, care was taken to lower the power output to $3 \mathrm{~W}$ of energy to avoid thermal damage to the underlying pulp. ${ }^{1}$

In the present study, the restored primary anterior teeth samples were subjected to thermo cycling in order to simulate thermal changes occurring in the oral cavity. Clinically, the amount of microleakage at the restoration margins is important because it could lead to post operative sensitivity, secondary caries and pain. ${ }^{17}$

Microleakage has been determined by many quantitative and qualitative methods that include the use of dyes, scanning electron microscope, electrochemical technique, nanotechnology and reversible radioactive adsorption. ${ }^{20-25}$ Dye penetration test was utilized in our study to assess microleakage. It is a widely used and generally preferred method because it is easily available, cheap, and non-toxic. ${ }^{26}$

In cavities that were conventionally prepared, etching with phosphoric acid resulted in removal of smear layer and exposure of enamel prism sheaths and dentinal tubules. ${ }^{27}$ In this study, microleakage was seen to be higher following conventional etching. This is probably because there are no definite etching patterns seen in primary teeth. There is only a surface roughing with no complete demineralization of dentin. Etching for a shorter duration of time has been seen to result in lower diffusion of hydrogen ions due to buffering action of the inorganic constituents present in enamel and dentin, which limits the extent of demineralization..$^{28-30}$

Surfaces produced by laser etching were found to be more irregular. Er,Cr:YSGG lasers have a wavelength of 2.78 $\mu \mathrm{m}$ which is absorbed by the hydroxyl ions present in hydroxyapatite. There is a low increase in temperature of the outer layer, without damaging adjacent tissues. When Er:YAG lasers are applied to dentin, the high energy causes an uneven irregular rough surface. ${ }^{31}$

There are controversies regarding microleakage with laser preparations. While some studies found no difference in terms of leakage between cavities prepared by laser and those prepared by conventional method, others have demonstrated that lasers are associated with higher leakage. Most of these investigations were on Er:YAG laser. ${ }^{3,5,11,32-34}$ Yamada et al stated that cavities prepared in primary teeth by Er:YAG lasers and restored with composite resins resulted in less microleakage that was similar to etched bur cavities. ${ }^{15}$

No significant differences were observed between Er,Cr:YSGG laser and conventional burs in microleakage at the cervical margins of composite restorations in permanent teeth. ${ }^{15,34}$ In another study, higher microleakage occurred with phosphoric acid etching following bur or laser cut surfaces than with surfaces created using only the laser. ${ }^{7}$ The highly irregular surfaces following laser treatment results in loss of smear layer, intact enamel rods and opening of dentinal tubules. ${ }^{15,27}$ In the absence of a smear layer, there can be improved adhesion due to better penetration of both primer and adhesive. ${ }^{3,13,27}$ Howev- 
er, Bertrand et al reported of better marginal adaptation of restorations in permanent teeth, when Er:YAG laser preparation was followed by total acid etching. ${ }^{35}$

In the present study, there was microleakage observed in both groups. Restoring teeth with composite resins is highly technique sensitive and procedural errors can affect the quality of the restoration. The presence of gaps at the resin-tooth interface can be due to poor adaptation or less penetration of resin material into dentinal tubules, entrapped air and inadequate curing of the material. ${ }^{15}$ Resins with good flow characteristics and surface treatment of laser-prepared cavities has been suggested for better wetting and penetration. ${ }^{15}$

Due to its higher water content, dentin presents a strong thermo-mechanical interaction with Er,Cr:YSGG laser irradiation. The absorption of laser energy is greater by inter-tubular dentin due to its higher collagen matrix and water content, which leads to an unexpected rapid rise in temperature and water evaporation. ${ }^{36}$ There is an increase in pressure leading to a series of mini explosions with expulsion of tissue particles, which are typical of laser irradiation and gives the appearance of small circular depression-like cavities in the treated surfaces. ${ }^{37}$ Unlike conventional rotary burs, there is no smear layer produced in cavities prepared by laser application. ${ }^{36}$ Due to the low surface energy of the smear layer, it interferes with adequate adhesion of restorative materials to both enamel and dentin. Thus, better bonding to lased dentin may result without the presence of a smear layer, ${ }^{38,39}$ which could also reduce microleakage.

Perception of pain was lower in children following the use of Er,Cr:YSGG laser for cavity preparation. ${ }^{40}$ Simple techniques involving less chair side time are preferred by both parents and patients.

\section{Conclusion}

In comparison to conventional burs, cavity preparation using Er,Cr:YSGG laser irradiation did not show any significant difference in microleakage of the composite restoration.

\section{Ethical Considerations}

This study has been approved by the ethical committee of the institutional review board.

\section{Conflict of Interests}

Authors declare that they have no conflict of interests.

\section{References}

1. American Academy of Pediatric Dentistry. Policy on the use of Lasers for pediatric dental patients. Pediatr Dent. 2014;36(6):75-77.

2. Jacobson B, Asgari A. Restorative dentistry for children using a hard tissue laser. Alpha Omegan. 2008;101(3):133139. doi:10.1016/j.aodf.2008.07.025.

3. Hossain M,Nakamura Y, Yamada Y,MurakamiY, Matsumoto K. Compositional and structural changes of human dentin following caries removal by Er,Cr:YSGG laser irradiation in primary teeth. J Clin Pediatr Dent. 2002;26(3):263-268. doi:10.17796/jcpd.26.4.t314pk16058200v0.

4. Celik EU, Ergücü Z, Türkün LS, Türkün M. Effect of different laser devices on the composition and microhardness of dentin. Oper Dent. 2008;33(5):496-501. doi:10.2341/07-127.

5. Palma Dibb RG, Milori Corona SA, Borsatto MC, Ferreira KC, Pereira Ramos R, DjalmaPécora J. Assessing microleakage on class $\mathrm{V}$ composite resin restorations after Er:YAG laser preparation varying the adhesive systems. J Clin Laser Med Surg. 2002;20(3):129-133. doi:10.1089/104454702760090209.

6. Esteves-Oliveira M, Zezell DM, Apel C, et al. Bond strength of self etching primer to bur -cut, Er, Cr:YSGG and Er:YAG lased dental surfaces. Photomed Laser Surg. 2007;25(5):373-380.

7. Shahabi S, Ebrahimpour L, Walsh LJ. Microleakage of composite resin restorations in cervical cavities prepared by Er,Cr:YSGG laser radiation. Aust Dent J. 2008;53(2):172175. doi:10.1111/j.1834-7819.2008.00028.x.

8. Moldes VL, Capp CI, Navarro RS, Matos AB, Youssef MN, Cassoni A. In vitro microleakage of composite restorations prepared by Er:YAG/Er,Cr:YSGG lasers and conventional drills associated with two adhesive systems. J Adhes Dent. 2009;11(3):221-229.

9. Baghalian A, Nakhjavani YB, Hooshmand T, Motahhary P, Bahramian H. Microleakage of Er:YAG laser and dental bur prepared cavities in primary teeth restored with different adhesive restorative materials. Lasers Med Sci. 2013;28(6):1453-1460. doi:10.1007/s10103-012-1222-0.

10. Gutknecht N, Apel C, Schäfer C, Lampert F. Microleakage of composite fillings in Er,Cr:YSGG laser-prepared class II cavities. Lasers Surg Med. 2001;28(4):371-374. doi:10.1002/ lsm.1064.

11. Marotti J, Geraldo-Martins VR, Bello-Silva MS, de Paula Eduardo C, Apel C, Gutknecht N. Influence of etching with erbium, chromium:yttrium-scandium-gallium-garnetlaser on microleakage of class V restoration. Lasers Med Sci. 2010;25(3):325-329.

12. Uekusa S, Yamaguchi K, Miyazaki M, Tsubota K, Kurokawa $\mathrm{H}$, Hosoya Y. Bonding efficacy of single- step self- etch systems to sound primary and permanent tooth dentin. Oper Dent. 2006;31:569-576. doi:10.2341/05-102.

13. Ovrebo RC, Raadal M. Microleakage in fissures sealed with resin or glass ionomer cement. Scand J Dent Res. 1990; 98(1):66-69. doi:10.1111/j.1600-0722.1990.tb00941.x.

14. Waggoner WF. Restoring primary anterior teeth. Pediatr Dent. 2002;24(5):511-516.

15. Yamada Y, Hossain M, Nakamura Y, Murakami Y, Matsumoto K. Microleakage of composite resin restoration in cavities prepared by Er:YAGlaser irradiation in primary teeth. Eur J Paediatr Dent. 2002 ;3(1):39-45. doi:10.1111/j.1600-0722.1990.tb00941.x.

16. Oznurhan F, Olmez A. Morphological analysis of the resindentin interface in cavities prepared with Er,Cr:YSGG laser or bur in primary teeth. Photomed Laser Surg. 2013 Aug;31(8):386-391. doi:10.1089/pho.2013.3498

17. Bahrololoomi Z, Heydari E. Assessment of tooth preparation via Er:YAG laser and bur on microleakage of dentin adhesives. J Dent (Tehran). 2014;11(2):172-178.

18. Gouw-Soares S, Pelino JE, Haypek P, Bachmann L, Eduardo CP. Temperature rise in cavities prepared in vitro by Er:YAG laser. J Oral Laser Appl. 2001;1:119-123.

19. Hossain M, Nakamura Y, Yamada Y, Kimura Y, Nakamura 
G, Matsumoto K. Ablation depths and morphological changes in human enamel and dentin after Er:YAGlaser irradiation with or without water mist. J Clin Laser Med Surg. 1999;17(3):105-109.

20. Taylor MJ, Lynch E. Microleakage. J Dent. 1992;20(1):3-10.

21. Yavuz I, Aydin AH. New method for measurement of surface areas of microleakage at the primary teeth by biomolecule characteristics of methilene blue. Biotechnol Biotechnol Eq. 2005;19(1):181-187. doi:10.1080/13102818. 2005.10817178.

22. Tjan A, Tan D. Microleakage at gingival margins of class $\mathrm{V}$ composite resin restorations rebonded with various lowviscosity resin systems. Quintessence Int. 1991;22(7):565573.

23. Pradelle-Plassea N, Wengerb F, Picarda B, Colona P. Evaluation of microleakage of composite resin restorations by an electrochemical technique: the impedance methodology. Dent Mater. 2004;20(5):425-434. doi:10.1016/j.dental.2003.06.003.

24. Yavuz I, Atakul F. Evaluation of microleaking in different in vitro restorations of cow permanent teeth. Balkan J Stomatol. 2001;5:42-45.

25. Sano H, Takatsu T, Ciucchi B, Horner JA, Matthews WG, Pashley DH. Nanoleakage: leakage within the hybrid layer. Oper Dent. 1995;20(1):18-25.

26. Baygin O, Korkmaz FM, Arslan I. Effects of different types of adhesive systems on the microleakage of compomer restorations in Class V cavities prepared by Er,Cr:YSGG laser in primary teeth. Dent Mater J. 2012;31(2):206-214. doi:10.4012/dmj.2011-133.

27. Hossain M, Yamada Y, Nakamura Y, Murakami Y, Tamaki Y, Matsumoto K. A study on surface roughness and microleakage test in cavities prepared by Er:YAG laser irradiation and etched bur cavities. Lasers Med Sci. 2003;18(1):25-31.

28. Sardella TN, de Castro FL, Sanabe ME, Hebling J. Shortening of primary dentin etching time and its implication on bond strength. J Dent. 2005;33(5):355-362. doi:10.1016/j.jdent.2004.10.011.

29. Osorio R, Aguilera FS, Otero PR, et al. Primary dentin etching time, bond strength and ultra-structure characterization of dentin surfaces. J Dent. 2010;38(3):222231. doi:10.1016/j.jdent.2009.11.001.

30. Camps J, Pashley DH. Buffering action of human dentin in vitro. J Adhes Dent. 2000;2(1):39-50.

31. Kohara EK, Hossain M, Kimura Y, Matsumoto K, Inoue M, Sasa R. Morpholgical and microleakage studies of the cavities prepared by Er:YAG laser irradiation in primary teeth. J Clin Laser Med Surg. 2002;20(3):141-147.

32. Chinelatti MA, Ramos RP, Chimello DT, Borsatto MC, Pécora JD, Palma-Dibb RG. Influence of the use of Er:YAG laser for cavity preparation and surface treatment in microleakage of resin-modified glass ionomer restorations. Oper Dent. 2004;29(4):430-436.

33. Aranha AC, Turbino ML, Powell GL, Eduardo Cde P. Assessing microleakage of class $\mathrm{V}$ resin composite restorations after Er:YAG laser and bur preparation. Lasers Surg Med. 2005;37(2):172-177.

34. Yazici AR, Yildırım Z, Antonson SA, et al. of the Er,Cr:YSGG laser with a chemical vapour deposition bur and conventional techniques for cavity preparation: a microleakage study. Lasers Med Sci. 2012;27(1):23-29. doi:10.1007/s10103-010-0833-6

35. Bertrand MF, Semez G, Leforestier E, Muller-Bolla M, Nammour S, Rocca JP. Er:YAG laser cavity preparation and composite resin bonding with a single-component adhesive system: relationship between shear bond strength and microleakage. Lasers Surg Med. 2006;38(6):615-623. doi:10.1002/lsm.20342

36. Shahabi S, Chiniforush N, Bahramian H, Monzavi A, Baghalian A, Kharazifard MJ. The effect of erbium family laser on tensile bond strength of composite to dentin in comparison with conventional method. Lasers Med Sci. 2013;28(1):139-142.

37. Ramos RP, Chimello DT, Chinelatti MA, Nonaka T, Pécora JD, Palma Dibb RG.Effect of Er:YAG laser on bond strength to dentin of a self-etching primer and two singlebottle adhesive systems. Lasers Surg Med. 2002;31(3):164170. doi:10.1002/lsm.10106.

38. Ekworapoj P, Sidhu SK, McCabe JF. Effect of different power parameters of Er, Cr:YSGG laser on human dentine. Laser Med Sci. 2007;23(3):175-182. doi:10.1016/j. jdent.2004.10.011.

39. Gurgan S, Kiremitci A, Cakir FY, Yazici E, Gorucu J, Gutknecht N. Shear bond strength of composite bonded to erbium:yttrium-aluminum-garnet laser-prepared dentin. Lasers Med Sci. 2009;24(1):117-122. doi:10.1016/j. jdent.2004.10.011.

40. Eren F, Altinok B, Ertugral F, Tanboga I. The effect of erbium, chromium:yttrium-scandium-gallium-garnet (Er,Cr:YSGG) laser therapy on pain during cavity preparation in pediatric dental patients: a pilot study. Oral Health Dent Manag. 2013;12(2):80-84. 